\title{
Whale of a catch blows hole in family tree
}

David Cyranoski, Tokyo

A whale carcass swarming with maggots has made a splash in the world of marinemammal research. The rotting remains were found by marine biologist Tadasu Yamada on a trip to a remote island in the Japan Sea in 1998 to examine a whale that died in a collision with a fishing boat.

Five years on, Yamada, of Tokyo's National Science Museum, and colleagues have shown that the whale represents a new species. The finding helps to resolve long-standing confusion about how many whale species there are. But it could create problems for whale conservation.

Scientists have long suspected that there are more than just the six recognized species of baleen whales of the genus Balaenoptera. Researchers thought that eight whales taken by Japanese research whaling boats in the late 1970s, for example, were part of a unique species - but they couldn't prove it.

Shiro Wada, a molecular biologist at Japan's National Research Institute of Fisheries Science in Yokohama, analysed enzymes in the liver and muscle of those specimens and found dramatic differences from common Bryde's whales (Balaenoptera brydei) which they resembled.

"I was sure that they were a different species, but that was a period when people didn't trust comparative enzyme studies for evolutionary studies," says Wada. The full carcasses of the whales were not kept for further study.

So when the 1998 whale carcass turned up, Wada, Yamada and their colleagues com-

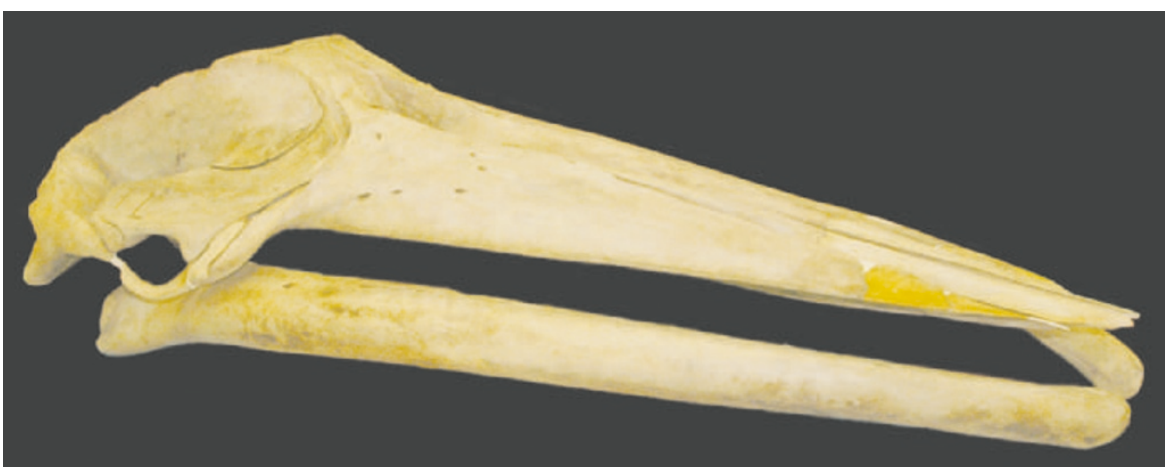

Analysis of the skull of a baleen whale found in 1998 suggests that it represents a new species.

pared the structure of the skull and baleen plates - sieve-like structures that baleen whales use to sift food - along with DNA from all nine whales, with other Balaenoptera whales. They conclude that all nine are members of a previously unknown species. They also confirm that Eden's whale (B. edeni) is distinct from Bryde's whale, bringing the total number of Balaenoptera species to eight.

The identification of the new species, announced on page 278 of this issue, should help inform estimates of whale abundances, says Justin Cooke, senior scientist at at the Centre for Ecosystem Management Studies near Freiburg, Germany, and a member of the World Conservation Union's Species Survival Committee. The union does not know how many Bryde's whales there are, because of confusion over the number of species.

The Japanese whaling community, which catches about 50 Bryde's whales in the west- ern northern Pacific each year for research purposes, estimates that there are 22,000 Bryde's whales in that part of the ocean.

Researchers at the Institute of Cetacean Research in Tokyo, who carry out much of the research whaling, deny that they are catching the new species. "We only catch the common Bryde's whale," says Luis Pastene, a population geneticist at the institute.

But Scott Baker, who studies whale population genetics at the University of Auckland, New Zealand, reckons that they can't be so sure. "Japan has been conveniently ignoring the taxonomic uncertainty," says Baker. "Until you understand the taxonomy, you can't be sure how many are out there or what you're hunting."

Baker adds that genetic methods are likely to uncover more 'hidden' biodiversity in the oceans over the next few years. But he doubts that there are many more baleen species left to find.

\section{Europe urged to counter nuclear proliferation threat}

\section{Geoff Brumfiel, Washington}

Nuclear reactors used for research in eastern Europe pose a significant proliferation risk, which the European Union (EU) should take much firmer action to diffuse. That is the message a founder of US non-proliferation programmes will deliver to a meeting of European politicians in Strasbourg this week.

Sam Nunn, a former senator from Georgia who co-authored a 1991 bill that committed billions of US dollars to securing the former Soviet Union's nuclear-weapons stockpile, says that Europe should take the lead in dismantling or safeguarding the dozen or more Soviet-built research reactors.

The reactors are fuelled by highly enriched uranium, which could be used in nuclear weapons. "It tends to be stuff you could carry out in a backpack or pickup truck," says Matthew Bunn, a proliferation expert at Harvard University's John F.
Kennedy School of Government in Cambridge, Massachusetts.

Nunn is attending an interparliamentary conference on nonproliferation in Strasbourg on 21 November, and says that he hopes to get the EU to address the issue more forcefully. "This issue should be of acute interest to our EU allies and friends," he says.

But Bruno Tertrais of the Foundation for Strategic Research in Paris, points out that non-proliferation

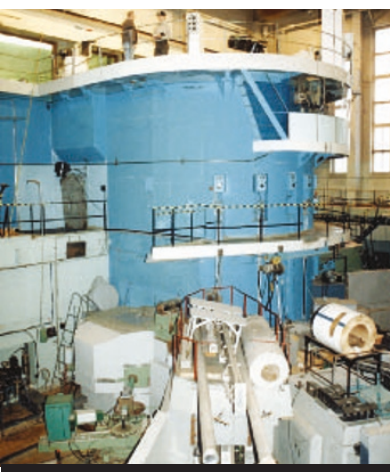

Slow to react: the Salaspils nuclear reactor in Latvia was closed in 1998 but not dismantled.
European issue," he says.

The low visibility of the problem in Europe has led to scant funding to counter weapons of mass destruction. Bunn says that between 1992 and 2000, Europe spent less than US\$500 million on nonproliferation, whereas the United States committed more than $\$ 6.5$ billion.

Research reactors would be a good focus for $\mathrm{EU}$ anti-proliferation efforts, says Michèle Flournoy of the Center for Strategic and issues tend to be seen in Europe as a matter for the United States and Russia to resolve. "It's extremely difficult to make our opinion and political leaders understand that this is a
International Studies in Washington DC. Several of the EU's new members in eastern Europe have reactors that house highly enriched uranium, says Flournoy. 